\title{
Voortijdig schoolverlaters
}

Citation for published version (APA):

Meng, C., \& Bles, P. (2017). Voortijdig schoolverlaters. ROA. ROA Fact Sheets No. 003

https://doi.org/10.26481/umarof.2017003

Document status and date:

Published: 01/01/2017

DOI:

10.26481/umarof.2017003

Document Version:

Publisher's PDF, also known as Version of record

\section{Please check the document version of this publication:}

- A submitted manuscript is the version of the article upon submission and before peer-review. There can be important differences between the submitted version and the official published version of record.

People interested in the research are advised to contact the author for the final version of the publication, or visit the DOI to the publisher's website.

- The final author version and the galley proof are versions of the publication after peer review.

- The final published version features the final layout of the paper including the volume, issue and page numbers.

Link to publication

\footnotetext{
General rights rights.

- You may freely distribute the URL identifying the publication in the public portal. please follow below link for the End User Agreement:

www.umlib.nl/taverne-license

Take down policy

If you believe that this document breaches copyright please contact us at:

repository@maastrichtuniversity.nl

providing details and we will investigate your claim.
}

Copyright and moral rights for the publications made accessible in the public portal are retained by the authors and/or other copyright owners and it is a condition of accessing publications that users recognise and abide by the legal requirements associated with these

- Users may download and print one copy of any publication from the public portal for the purpose of private study or research.

- You may not further distribute the material or use it for any profit-making activity or commercial gain

If the publication is distributed under the terms of Article $25 \mathrm{fa}$ of the Dutch Copyright Act, indicated by the "Taverne" license above, 
U. Maastricht University in Learning!

Research Centre for Education and the Labour Market | ROA

\section{Voortijdig schoolverlaters}

\section{ROA Fact Sheet}

ROA-F-2017/3

Researchcentrum voor Onderwijs en Arbeidsmarkt | ROA Research Centre For Education and the Labour Market / ROA 


\section{Inleiding}

In navolging van het in kaart brengen van de onderwijsen arbeidsmarktpositie van gediplomeerde jongeren in het jaarlijkse ROA-rapport 'Schoolverlaters tussen onderwijs en arbeidsmarkt', wordt in deze Fact Sheet aandacht besteed aan degenen die de school niet gediplomeerd verlaten: voortijdig schoolverlaters (vsv'ers). In deze Fact Sheet zullen onder andere redenen om het onderwijs te verlaten worden besproken. Ook worden vragen als "wat waren de vroege signalen van de uitval?", "wat doen de vsv'ers nu?", "wat zijn hun toekomstplannen?" en "hebben ze spijt van het afbreken van de opleiding?” beantwoord.

Voortijdig schoolverlaters zijn jongeren die een opleiding verlaten zonder dat ze daarbij een diploma hebben gehaald en daarmee een startkwalificatie voor de arbeidsmarkt bezitten. Een startkwalificatie voor de arbeidsmarkt geeft aan welke opleidingen jongeren voldoende voorbereiden op de arbeidsmarkt: havo/vwo en mbo niveau 2 of hoger. Opleidingen die dus geen startkwalificatie voor de arbeidsmarkt bieden zijn vmbo en mbo niveau I.

De in deze Fact Sheet gepresenteerde cijfers zijn afkomstig van enquêtes die in het najaar van 2016 door het CBS zijn afgenomen en onderdeel zijn van het project SchoolverlatersInformatieSysteem (SIS) van het Researchcentrum Onderwijs en Arbeidsmarkt (ROA) van de Universiteit Maastricht (UM). Het betreft 2.262 voortijdig schoolverlaters die in schooljaar 2014/20I5 gestopt zijn met hun opleiding en de enquête hebben ingevuld. Jongeren die een vmbo- of mbo niveau I opleiding afgerond hebben, worden niet meegenomen in dit onderzoek, omdat ze feitelijk gesproken niet voortijdig zijn uitgevallen; deze jongeren hebben wel een diploma, maar geen startkwalificatie.

\section{Achtergrondkenmerken van de respondenten}

Wie zijn de voortijdig schoolverlaters eigenlijk? In deze paragraaf wordt getracht daar een antwoord op te formuleren. Aan de hand van enkele achtergrondkenmerken van de vsv'ers zal een beeld worden geschetst van deze groep jongeren. Een uitgebreide tabel met de verdeling van de vsv'ers over enkele achtergrondkenmerken is te vinden in Tabel Bı in de Bijlage. ${ }^{\mathrm{I}}$

\section{Opleidingskenmerken}

De overgrote meerderheid van de respondenten komt van het mbo (80\%). Ongeveer 25\%-punt daarvan valt uit van mbo-bol niveau 4 opleidingen. Ook van bol-niveau 2 vallen veel leerlingen uit (2I\%-punt). Ongeveer II\%-punt van de uitvallers komt van het mbo-bbl niveau 2. Ongeveer $9 \%$ valt uit de havo-opleiding en $8 \%$ van de vmbo-opleiding. Van het vwo valt slechts $3 \%$ uit.

I Voor een overzicht van kenmerken van gediplomeerden, zie de SIS-online website; https://roastatistics.maastrichtuniversity.nl/ SISOnline/Home.aspx.
De uitval is over alle niveaus het grootst voor de sector Economie, waar gemiddeld $35 \%$ van de respondenten vandaan komt. Techniek volgt op de tweede plaats met $23 \%$. Ongeveer $14 \%$ valt uit in de sector Gezondheidzorg, terwijl 6\% van de respondenten is begonnen aan opleiding in de sector Gedrag \& Maatschappij. Ongeveer 3\% van de respondenten heeft een opleiding in de sector Landbouw gedaan.

\section{Leeftijd en geslacht}

De respondenten zijn ongeveer anderhalf jaar na het verlaten van de opleiding gemiddeld 20,I jaar oud. Respondenten afkomstig van een havo- of vwo-opleiding zijn gemiddeld 19,6 jaar oud. Respondenten van het vmbo zijn I8,3 jaar oud. De gemiddelde leeftijd van mbo'ers die de opleiding niet hebben afgemaakt, is 20,3 jaar.

Er zijn duidelijk meer mannen die voortijdig stoppen met hun opleiding, dan vrouwen. Het percentage mannen onder alle respondenten is $62 \%$, terwijl er maar $38 \%$ vrouw is. Dit verschilt echter wel tussen de verschillende opleidingsniveaus. Op het havo en vwo is de verdeling ook 62\% man, $38 \%$ vrouw. Ongeveer $65 \%$ van de vmbo'ers is man en dus $35 \%$ vrouw. Nagenoeg $70 \%$ van de uitvallers van mbo niveau I opleidingen is man en dus $30 \%$ vrouw. Twee derde van de mbo niveau 2 uitvallers is man en ongeveer $58 \%$ van de mbo niveau 3 schoolverlaters behoord tot het mannelijke geslacht. Tot slot is ongeveer $56 \%$ van de uitvallers op mbo niveau 4 man.

\section{Etniciteit}

Van alle respondenten is $62 \%$ autochtoon. Onder leerlingen op het havo is dit percentage het grootst, namelijk $72 \%$. Op het vwo is $71 \%$ autochtoon. Op de havo is $8 \%$ westerse allochtoon en op het vwo is dat II\%. Het havo kent daarnaast $20 \%$ niet-westerse allochtonen die vroegtijdig de opleiding verlaten. Voor vwo is dat percentage 19. Op het vmbo is de grootste groep uitvallers van niet-westerse afkomst (43\%). Het aantal uitvallende autochtonen op het vmbo bedraagt $42 \%$, en $15 \%$ bestaat uit westerse allochtonen.

Op mbo niveau I geldt dat zowel het percentage autochtonen als niet-westerse allochtonen beide $44 \%$ is. Ongeveer I2\% van de westerse allochtonen verlaat de opleiding voortijdig. Van de respondenten op mbo niveau 2 is $64 \%$ autochtoon, $31 \%$ niet-westers allochtoon en $6 \%$ westers allochtoon. Ongeveer 7 op de Io uitvallers op opleidingen van mbo niveau 3 zijn autochtoon, 2I\% niet-westers en $9 \%$ westers allochtoon. Voor mbo niveau 4 geldt dat $63 \%$ autochtoon is, $29 \%$ niet-westers allochtoon en $9 \%$ westers allochtonen.

\section{Thuissituatie}

Ongeveer 6 op de Io respondenten komt uit een tweeoudergezin, ongeveer 3 op de Io komt uit een eenoudergezin en ongeveer $9 \%$ woont zelfstandig. Om en nabij $63 \%$ van de havo/vwo vsv'ers woont in een tweeoudergezin en dit percentage daalt op het vmbo en mbo naar respectievelijk $60 \%$ en $57 \%$. Deze daling komt op het mbo bijna volledig 
op het conto van de zelfstandigen, die net iets minder dan I $6 \%$ van de respondenten op het mbo uitmaakt.

Thuis wordt door $65 \%$ van de schoolverlaters (bijna) altijd Nederlands gesproken. In $18 \%$ van de gevallen is dat Nederlands en een andere taal en $6 \%$ van de respondenten spreekt (bijna) altijd een andere taal. De verschillen tussen de opleidingsniveaus zijn groot. Van havo/vwo respondenten spreekt $75 \%$ Nederlands thuis, terwijl dit percentage voor mbo op $65 \%$ en voor vmbo op 50\% ligt.

Het opleidingsniveau van de ouders is onder alle opleidingsniveaus van de opleiding waarvan de respondenten komen het vaakst het hoger onderwijs (45\%). Voor havo/ vwo uitvallers is dit ongeveer $70 \%$, voor vmbo'ers is dit $53 \%$ en voor mbo'ers $40 \%$.

\section{Belangrijkste reden om te stoppen}

Wie zijn uitgevallen in het onderwijs is duidelijk geworden aan de hand van de vorige paragraaf, maar dat geeft nog geen inzicht in waarom men is uitgevallen. In deze paragraaf zal inzicht gegeven worden waarom de jongeren voortijdig zijn gestopt met hun opleiding. De redenen staan per categorie weergegeven in Figuur I. De meer specifieke redenen staan vermeld in de Tabel $\mathrm{B}_{2}$ in de Bijlage.

Bijna de helft van de redenen die aangevoerd worden om te stoppen is schoolgerelateerd $(47 \%)$. Ook gezondheidsproblemen (I8\%) en de lonkende arbeidsmarkt (I4\%) worden relatief vaak genoemd. Onderaan de lijst staat de categorie persoonlijke problemen (9\%).

\section{Figuur 1}

Belangrijkste reden voor uitval

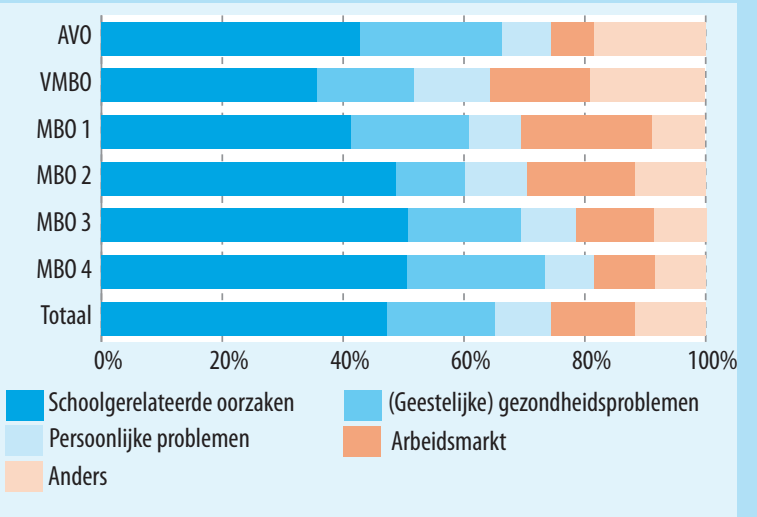

\section{Schoolgerelateerd}

Het vaakst werden schoolgerelateerde problemen genoemd als redenen voor het stoppen met de opleiding op mbo niveau 3 en 4 (beide $51 \%$ ). Het minst werd deze reden aangevoerd door voortijdig schoolverlaters van het vmbo $(36 \%)$.

De onderliggende schoolgerelateerde redenen die genoemd worden, laten zien dat de belangrijkste reden inhoudelijk van aard is. De reden de opleiding was inhoude- lijk (toch) niet wat ik wilde wordt het vaakst genoemd (13\%), het meest door uitvallers van mbo niveau 4 (I9\%) en niveau 3 (I8\%). De reden de opleiding was slecht georganiseerd wordt het op een na vaakst genoemd $(8 \%)$ en het vaakst door mbo niveau 2 en 4 uitvallers (beide 9\%). De reden de opleiding was te moeilijk/gezakt voor het eindexamen werd gemiddeld genomen niet vaak genoemd ( $7 \%)$, maar door voortijdig schoolverlaters op het havo en het vwo wordt deze reden het vaakst het belangrijkst gevonden (22\%).

\section{(Geestelijke) gezondheidsklachten}

$\mathrm{Na}$ de schoolgerelateerde oorzaken van uitval, zijn de gezondheidsklachten de belangrijkste oorzaak van voortijdig schooluitval (I8\%). De reden wordt het vaakst genoemd op het avo $(24 \%)$ en op mbo niveau $4(23 \%)$, daarna mbo niveau I $(20 \%)$ en mbo niveau 3 (19\%). Het minst vaak wordt de reden gegeven op het vmbo (I6\%) en mbo niveau 2 (II\%).

Van de genoemde gezondheidsklachten worden psychische problemen het vaakst genoemd (IO\%); ziekte wordt ongeveer in $8 \%$ van de gevallen als belangrijkste oorzaak voor de uitval genoemd. Psychische problemen worden het vaakst genoemd op het havo en vwo (I4\%), maar een stuk minder mbo niveau 2 ( $7 \%)$.

\section{Arbeidsmarkt}

De arbeidsmarkt is de op twee na belangrijkste reden voor vroegtijdige uitval. Ongeveer $\mathrm{I} 4 \%$ van de voortijdig schoolverlaters geeft aan dat de arbeidsmarkt de belangrijkste reden voor het stoppen met de opleiding is. In het voorgaande jaar was dit percentage I2\%, wat zou kunnen duiden op een verbetering van de arbeidsmarkt. Door een aantrekkende arbeidsmarkt worden jongeren verleid om ongediplomeerd het onderwijs te verlaten. Ongeveer IO\% van de voortijdig schoolverlaters werd naar de arbeidsmarkt toe getrokken: zij wilden liever gaan werken dan naar school. Het vaakst wordt deze reden voor uitvallers op mbo niveau I genoemd (I9\%). Ongeveer $4 \%$ van de respondenten werd naar de arbeidsmarkt toe geduwd: zij hadden een inkomen nodig en zijn gaan werken. Deze reden werd op mbo niveau 3 het meeste genoemd ( $7 \%)$.

\section{Persoonlijke problemen}

Ongeveer 9\% van de respondenten geeft aan dat persoonlijke problemen de belangrijkste factor waren in het voortijdig uit het onderwijs stappen. De belangrijkste onderliggende reden zijn relatie- of gezinsproblemen $(7 \%)$. Deze reden wordt over de opleidingsniveaus heen ongeveer even vaak genoemd. In aanraking komen met politie en justitie komt het vaakst voor op vmbo niveau (4\%), terwijl deze praktisch afwezig is op andere opleidingsniveaus.

\section{Anders}

Van de voortijdig schoolverlaters heeft $12 \%$ aangeven dat een andere reden het belangrijkst was voor de uitval uit het onderwijs, dan de redenen die vermeld staat in het onderzoek. Vooral op het middelbaar onderwijs is deze groep schoolverlaters groot: op het vmbo wordt deze optie $19 \%$ 
van de gevallen als belangrijkst gezien, op het avo is dit percentage ook $19 \%$.

\section{Vroege signalen bij uitval}

Het is de overheid er veel aan gelegen om het aantal voortijdig schoolverlaters terug te dringen. Het tijdig signaleren van het voortijdig willen verlaten van de opleiding kan daarbij helpen. ${ }^{2}$ Aan de vsv'ers is gevraagd met wie gepraat is over de beslissing om te willen stoppen en wie geholpen heeft met het voorkomen van de uitval.

\section{Praten over de beslissing}

Aan de respondenten is gevraagd of zij met iemand hebben gepraat over de beslissing om voortijdig met de opleiding te stoppen. In Tabel I is per opleidingsniveau weergegeven of de vroegtijdige uitvallers met iemand gesproken hebben over de keuze om met de opleiding te stoppen. Als dat zo was, dan is ook vermeld of dat met de ouders, met het gezin of vrienden of met de leraren of mentoren is geweest. Bij ongeveer 8 op de Io voortijdig uitvallers heeft er een gesprek plaatsgevonden over het voortijdig uitvallen van de opleiding (78\%). Van de respondenten die aangaven met niemand te hebben gesproken (22\%), zijn de meeste afkomstig van mbo niveau I of 2 ( $28 \%$ en $26 \%$ respectievelijk); ook op het vmbo beslaat deze groep een kwart van de respondenten.

Indien de respondent met iemand gesproken heeft, is dat in driekwart van de gevallen met de ouders ( $77 \%)$, meer dan de helft van de respondenten praat met de school $(56 \%)$ en ongeveer drie op de tien respondenten praat met het gezin of vrienden over de aanstaande voortijdig uitval. Dat deze percentages niet optellen tot honderd procent, komt omdat respondenten meerdere antwoorden kon aankruisen. Van alle respondenten heeft $42 \%$ één antwoord gegeven, $26 \%$ heeft twee antwoorden en $\mathrm{I} \%$ heeft alle drie de antwoorden gegeven.

De voortijdig schoolverlaters op het havo en vwo die met iemand gepraat hebben, praatten het meeste met hun ouders: $88 \%$ heeft gepraat over de uitval met hun ouders. Van de respondenten die aangegeven hebben te hebben gepraat met de school zaten de meesten op mbo niveau 4 $(62 \%)$, terwijl dat percentage op het vmbo slechts $43 \%$ is.

\section{Aangeboden hulp}

Naast de signalering die er van een gesprek over de uitval uitgaat, kan ook worden afgeleid dat een leerling zou kunnen uitvallen aan de hand van de hulp die deze leerling heeft gehad om het diploma te behalen of een andere opleiding te kiezen. Aan voortijdig schoolverlaters is gevraagd of ze hulp ervaren hebben om de voortijdige uitval te voorkomen. In Tabel 2 staat vermeld in hoeverre dat het geval is geweest. In totaal hebben $65 \%$ van de voortijdig schoolverlaters hulp van iemand ervaren om het diploma te behalen

2 https://www.rijksoverheid.nl/onderwerpen/vsv of een andere opleiding te kiezen. Op het vmbo wordt het vaakst hulp geboden ( $77 \%$ ) en op mbo niveau 4 opleidingen wordt het minst vaak hulp aangeboden (6r\%).

Wanneer de arbeidsmarkt als belangrijkste reden voor de uitval werd genoemd, is het meest hulp geboden om de opleiding niet voortijdig te verlaten $(71 \%)$; ook bij gezondheids- en persoonlijke problemen ( $69 \%$ en $68 \%$ ) is relatief vaak geprobeerd te helpen om de uitval te voorkomen. De minste hulp wordt geboden indien het gaat om schoolgerelateerde uitval $(60 \%)$. De aard van de reden zou een verklaring kunnen bieden voor dit verschil. Onder schoolgerelateerde uitval wordt onder andere zakken voor examens, inhoudelijke desinteresse en problemen met de school geschaard. Wanneer men problemen heeft met de school is het niet logisch om vervolgens hulp te vragen bij dezelfde school.

Ongeveer een op de twee respondenten die hebben aangegeven dat ze met niemand over de uitval hebben gesproken, hebben ook het idee dat niemand geprobeerd heeft te helpen $(46 \%)$. Ongeveer drie op de tien respondenten heeft het gevoel geen hulp te hebben gehad, nadat ze er met iemand over gesproken hebben (32\%). Wanneer wordt gekeken naar de groep respondenten die met iemand over de uitval gesproken heeft, krijgt ongeveer $26 \%$ geen hulp als zij met de school gesproken hebben, terwijl dit percentage voor vrienden en ouders respectievelijk op 32\% en $34 \%$ ligt. Het lijkt er dus op dat hulp sneller geboden wordt als men met de school praat over de uitval, dan wanneer dat met familie of vrienden gebeurd.

\section{Huidige bezigheden}

Wat de voortijdig uitvallers zijn gaan doen nadat zij zijn uitgevallen, kan het beste worden beantwoord met de vraag wat zij op het moment van enquête aan het doen waren. Zij zijn dan immers al uitgevallen in de anderhalf jaar die aan het enquêtemoment vooraf gingen. In Tabel 3 staan de huidige bezigheden beschreven. Ongeveer vier op de tien voortijdig schoolverlaters is aan het werk (40\%), en ongeveer $29 \%$ is met een opleiding bezig en nog eens $\mathrm{II} \%$ is bezig met een werk/leertraject. Ongeveer 8\% kan tot de werkloze beroepsbevolking worden gerekend, terwijl ongeveer $12 \%$ een andere bezigheid heeft.

De diversiteit tussen de opleidingsniveaus is groot. Uitvallers op het havo en het vwo zijn in meerderheid opnieuw met een opleiding begonnen ( $51 \%)$ en onder hen is ongeveer $24 \%$ aan het werk. Op het vmbo werkt $22 \%$ en gaat $42 \%$ naar school toe. Op de verschillende mbo niveaus is werken prevalenter. De helft van de vsv'ers op niveau I en 2 werkt ( 50 en $51 \%$ respectievelijk). Opmerkelijk is ook dat iets meer dan $10 \%$ van de respondent zou willen werken, maar nog geen werk heeft ( $13 \%$ en $\mathrm{II} \%)$. Over alle niveaus is het volgen van een leer/werk-traject ongeveer hetzelfde en ligt rond de $\mathrm{II} \%$.

De voortijdig schoolverlaters die school voortijdig verlaten hebben vanwege de arbeidsmarkt werken het 
Tabel 1

Met wie heb je gesproken over je keuze om met de opleiding te stoppen? (meerdere antwoorden mogelijk)(\%)

\begin{tabular}{|c|c|c|c|c|c|c|c|}
\hline & AV0 & VMBO & MBO 1 & $\mathrm{MBO} 2$ & MBO 3 & $\mathrm{MBO} 4$ & Totaal \\
\hline lemand & 79 & 75 & 72 & 74 & 84 & 81 & 78 \\
\hline Niemand & 21 & 25 & 28 & 26 & 16 & 19 & 22 \\
\hline Ouders & 88 & 82 & 65 & 72 & 78 & 80 & 77 \\
\hline Gezin/Vrienden & 36 & 23 & 14 & 23 & 30 & 36 & 29 \\
\hline Leraren/mentoren/begeleiders/zorgadviesteam op school & 55 & 43 & 56 & 53 & 58 & 62 & 56 \\
\hline
\end{tabular}

\section{Tabel 2}

Wie heeft je geprobeerd te helpen om de voortijdige uitval te voorkomen? (\%)

\begin{tabular}{|l|r|r|r|r|}
\hline & Nemand heeft geholpen om uitval te voorkomen & Niemal geholpen om uitval te voorkomen \\
\hline Totaal & 65 & 35
\end{tabular}

\section{Belangrijkste reden uitval}

Schoolgerelateerde oorzaken

(Geestelijke) gezondheidsproblemen

Persoonlijke problemen

Arbeidsmarkt

Anders

\begin{tabular}{l|l|}
\hline 60 & 40 \\
\hline 69 & 31 \\
\hline 68 & 33 \\
\hline 71 & 39 \\
\hline 65 & 36 \\
\hline
\end{tabular}

\section{Opleidingsniveau}

\begin{tabular}{|c|c|c|}
\hline AVO & 64 & 36 \\
\hline VMBO & 77 & 23 \\
\hline MBO 1 & 70 & 30 \\
\hline MBO 2 & 63 & 37 \\
\hline MBO 3 & 65 & 35 \\
\hline MBO 4 & 61 & 39 \\
\hline \multicolumn{3}{|c|}{ Voortijdige uitvaller heeft gesproken met } \\
\hline lemand & 68 & 32 \\
\hline Niemand & 55 & 46 \\
\hline Ouders & 67 & 34 \\
\hline Gezin/vrienden & 68 & 32 \\
\hline Leraren, mentor & 75 & 26 \\
\hline
\end{tabular}


Tabel 3

Belangrijkste bezigheid op enquetemoment (\%)

\begin{tabular}{|c|c|c|c|c|c|}
\hline & Werk & Studie & $\begin{array}{r}\text { Combinatie werken/ } \\
\text { leren }\end{array}$ & Anders & Werkloos \\
\hline AVO & 24 & 51 & 11 & 10 & 4 \\
\hline VMBO & 22 & 42 & 13 & 16 & 7 \\
\hline MBO 1 & 50 & 13 & 11 & 14 & 13 \\
\hline MBO 2 & 51 & 17 & 10 & 11 & 11 \\
\hline $\mathrm{MBO} 3$ & 44 & 29 & 10 & 8 & 9 \\
\hline MBO 4 & 35 & 32 & 13 & 14 & 6 \\
\hline Totaal & 40 & 29 & 11 & 12 & 8 \\
\hline Schoolgerelateerde oorzaken & 40 & 33 & 12 & 6 & 8 \\
\hline (Geestelijke) gezondheidsproblemen & 26 & 25 & 9 & 29 & 11 \\
\hline Persoonlijke problemen & 30 & 29 & 16 & 11 & 14 \\
\hline Arbeidsmarkt & 77 & 7 & 7 & 3 & 6 \\
\hline Anders & 32 & 30 & 10 & 20 & 7 \\
\hline
\end{tabular}

\section{Tabel 4}

Van plan om op een later tijdstip nog opleiding te gaan volgen? (\%)

\begin{tabular}{|l|r|r|r|r|r|r|r|}
\hline Ja, alweer ingeschreven bij een opleiding & AV0 & VMBO & MB0 1 & MB02 & MB0 \\
\hline Ja, maar ik weer nog niet welke opleiding of wanneer & 10 & 16 & 5 & 11 \\
\hline Nee & 79 & 59 & 70 & 65 \\
\hline
\end{tabular}

\section{Tabel 5}

Wat houdt je tegen om met een nieuwe opleiding te beginnen? (meerdere antwoorden mogelijk)(\%)

\begin{tabular}{|c|c|c|c|c|c|c|c|}
\hline & AVO & VMBO & MBO 1 & $\mathrm{MBO} 2$ & $\mathrm{MBO} 3$ & $\mathrm{MBO} 4$ & Totaal \\
\hline Ik weet niet welke opleidingen er zijn & 13 & 15 & 15 & 13 & 16 & 12 & 14 \\
\hline De opleiding die ik wil doen heeft geen plek meer vrij & 3 & 4 & 5 & 6 & 2 & 4 & 5 \\
\hline De opleiding die ik wil doen is te ver weg & 3 & 1 & 2 & 4 & 5 & 3 & 3 \\
\hline Ik voldoe niet aan de minimale eisen om met de opleiding te beginnen & 21 & 17 & 28 & 18 & 12 & 11 & 17 \\
\hline Ik moet nog wachten omdat dit slechts op een beperkt aantal momenten kan & 17 & 4 & 9 & 6 & 8 & 11 & 8 \\
\hline De kosten zijn te hoog & 16 & 23 & 30 & 30 & 29 & 29 & 28 \\
\hline Ik kan via mijn werk verder leren & 7 & 5 & 10 & 10 & 15 & 14 & 11 \\
\hline Ik heb geen verdere studie nodig & 3 & 7 & 5 & 6 & 7 & 6 & 6 \\
\hline Ik wil me door middel van cursussen verder ontwikkelen & 14 & 6 & 12 & 14 & 14 & 19 & 14 \\
\hline Het is niet mogelijk vanwege persoonlijke omstandigheden & 20 & 14 & 16 & 19 & 18 & 22 & 19 \\
\hline Ik heb geen zin meer in het onderwijs & 13 & 17 & 10 & 24 & 21 & 23 & 21 \\
\hline Anders, namelijk & 34 & 34 & 18 & 22 & 22 & 28 & 25 \\
\hline
\end{tabular}


vaakst $(77 \%)$ en studeren het minst vaak (7\%). Persoonlijke problemen leiden het vaakst tot werkloosheid (I4\%), wat kan indiceren dat de problemen op school ook een probleem vormen op de arbeidsmarkt. Echter, de groep met persoonlijke problemen volgt ook het vaakst een leer/werk-traject (I6\%). Vsv'ers die aangaven dat schoolgerelateerde oorzaken de belangrijkste oorzaak waren voor de uitval, volgen relatief gezien het vaakst opnieuw een opleiding (33\%).

\section{Toekomstplannen}

Buiten de huidige bezigheden van de voortijdig schoolverlaters, is hen ook gevraagd wat hun plannen voor de toekomst zijn en voornamelijk of ze weer de intentie hebben om met een opleiding te beginnen. In hoeverre jongeren weer naar school willen gaan, laat ook zien in hoeverre jongeren bezig zijn om toch die startkwalificatie voor de arbeidsmarkt te behalen. Jongeren die op het moment van enquête weer in het onderwijs zitten, worden buiten beschouwing gelaten.

\section{Opleidingsplannen}

Zoals te zien is in Tabel 4, is van de voortijdig schoolverlaters die nog niet opnieuw een opleiding volgen, $75 \%$ van plan om op een later tijdstip nog een opleiding te gaan volgen. Van de $75 \%$ heeft ongeveer $8 \%$-punt zich al ingeschreven voor een opleiding. Ongeveer $25 \%$ is van plan om in de toekomst geen opleiding meer te volgen. De percentages zien er over de opleidingsniveaus heen anders uit. Voortijdig schoolverlaters van het vwo en het havo willen in de grootste getalen weer in het onderwijs terugkeren: $88 \%$ wil weer een opleiding gaan volgen, en IO\%-punt heeft zich al weer ingeschreven. Op het vmbo wil $75 \%$ aan een nieuwe opleiding beginnen, waarvan I6\%-punt zich al heeft ingeschreven. Op het mbo niveau I wil $75 \%$ zich opnieuw laten opleiden; op mbo niveau 2 is dat $69 \%$, op mbo niveau 3 is dat $76 \%$ en op mbo niveau 4 is dat ongeveer 8 op de Io vsv'ers.

\section{Afremmende factoren}

Aan de respondenten die zich nog niet ingeschreven hebben voor een nieuwe opleiding, is ook gevraagd welke factoren hen tegenhouden om met een nieuwe opleiding te beginnen (zie Tabel 5). De meeste genoemde reden waren de te hoge kosten die aan een opleiding verbonden zijn $(28 \%)$; deze optie werd het minst aangeduid als reden door de havo en vwo voortijdig schoolverlaters ( $16 \%$ ) en het vmbo ( $23 \%)$, alle andere niveaus liggen rond de $28 \%$ procent. De op een na meest genoemde reden is dat men geen zin meer heeft in het onderwijs (21\%). Deze reden is vooral genoemd door voortijdig schoolverlaters van mbo niveaus 2 , 3 en 4 en minder door mbo niveau I, vmbo- en avo-schoolverlaters. De op twee na meest genoemde reden zijn persoonlijke omstandigheden (19\%), die het meest worden genoemd door voortijdig schoolverlaters van mbo niveau 4. Opvallend is ook dat bij alle redenen de schoolverlaters van het avo (havo/vwo) de reden anders vaker aankruisen (34\%) dan de andere opleidingsniveaus (iets meer dan 20\%) en de andere remmende factoren substantieel minder vaak aankruisen dan de andere opleidingsniveaus. Blijkbaar is er een andere niet nader omschreven reden die voormalig havisten en vwo'ers doet besluiten geen nieuwe opleiding te beginnen.

\section{Stimulerende factoren}

Naast de afremmende factoren voor het beginnen van een nieuwe opleiding, is ook gevraagd naar stimulansen die de eventuele barrières zouden kunnen wegnemen (Tabel 6). Uit de antwoorden die de vsv'ers die nog niet opnieuw staan ingeschreven bij een opleiding hebben gegeven, blijkt dat vooral geld een rol speelt in het niet starten met een nieuwe opleiding. Van de respondenten geeft $37 \%$ aan dat financiële steun van de gemeente een stimulans zou kunnen zijn. Ook het krijgen van studiefinanciering wordt door $34 \%$ van de respondenten genoemd; opmerkelijk is dat hier de vsv'ers afkomstig van het avo relatief vaak aangeven dat studiefinanciering een stimulans kan zijn (48\%).

Naast geld is ook tijd een belemmerende factor. Ongeveer $31 \%$ van de respondenten geeft aan dat ze een opleiding zouden kunnen starten als deze naast hun huidige baan zou kunnen worden gevolgd.

\section{Spijt achteraf}

Aan het einde van de enquête is aan de voortijdig schoolverlaters gevraagd of zij spijt hebben van hun keuze om voortijdig met de opleiding te stoppen. In Tabel 7 zijn deze percentages uitgesplitst naar opleidingsniveau en in Tabel 8 naar de reden van de uitval.

\section{Spijt naar opleidingsniveau}

Van alle vsv'ers heeft de helft (50\%) geen spijt van de keuze om voortijdig met de opleiding te stoppen. Dit percentage ligt voor vsv'ers afkomstig van het avo, vmbo, mbo niveau 3 en 4 allen rond de $55 \%$. Het laagst is dit percentage voor mbo niveau I (37\%). Het meeste spijt door een gedwongen afscheid van de opleiding komt voor bij vsv'ers van mbo niveau I en 2 (beide $37 \%$ ). Het laagste percentage is te vinden bij uitvallers van het vmbo $(30 \%)$ en mbo niveau 4 $(31 \%)$. Evenzeer zijn de meeste spijtoptanten te vinden bij mbo niveau I wanneer het vertrek ongedwongen was (26\%). Het minste spijt van een ongedwongen vertrek hebben vsv'ers van het havo en het vwo (I2\%).

\section{Spijt naar reden van de uitval}

Voortijdig schoolverlaters die vanwege schoolgerelateerde of arbeidsmarktgerelateerde redenen uitvielen, hebben het minste spijt van hun voortijdig vertrek ( $56 \%$ en $59 \%$ ). De meeste spijtoptanten zijn diegene die de opleiding verlaten hebben vangwege persoonlijke problemen $(72 \%)$, waarvan $55 \%$-punt niet anders kon. De grootste groep vsv'ers met spijt over het verlaten van de opleiding, maar destijds niet anders konden, heeft de opleiding verlaten vanwege gezondheidsproblemen ( $57 \%)$. Het minste aantal uitvallers, 
Tabel 6

Wat zou je kunnen stimuleren om met een nieuwe opleiding te beginnen? (meerdere antwoorden mogelijk)(\%)

\begin{tabular}{|c|c|c|c|c|c|c|c|}
\hline & AV0 & VMBO & MBO 1 & $\mathrm{MBO} 2$ & MBO 3 & MB04 & Totaal \\
\hline Het krijgen van studiefinanciering & 48 & 31 & 31 & 31 & 27 & 39 & 34 \\
\hline Financiële steun van de gemeente & 38 & 29 & 36 & 37 & 34 & 40 & 37 \\
\hline Als ik de opleiding naast mijn huidige baan zou kunnen volgen & 30 & 20 & 33 & 30 & 32 & 33 & 31 \\
\hline Als ik op korte termijn zou kunnen beginnen & 18 & 10 & 19 & 15 & 16 & 14 & 15 \\
\hline Hulp bij de studiekeuze zodat ik weet wat voor een opleiding ik wil gaan doen & 35 & 21 & 17 & 24 & 27 & 27 & 25 \\
\hline Anders, namelijk & 24 & 32 & 19 & 28 & 26 & 25 & 26 \\
\hline
\end{tabular}

Tabel 7

Spijt achteraf, naar opleidingsniveau (\%)

\begin{tabular}{|c|c|c|c|c|c|c|c|}
\hline & AVO & VMBO & MB0 1 & $\mathrm{MBO} 2$ & MBO 3 & MBO 4 & Totaal \\
\hline $1 \mathrm{Nee}$ & 55 & 56 & 37 & 44 & 53 & 56 & 50 \\
\hline $2 \mathrm{Ja}$, dat zou ik nu niet meer doen & 12 & 14 & 26 & 19 & 14 & 13 & 16 \\
\hline \multirow[t]{2}{*}{$3 \mathrm{Ja}$, maar ik kon destijds niet anders } & 33 & 30 & 37 & 37 & 33 & 31 & 34 \\
\hline & 100 & 100 & 100 & 100 & 100 & 100 & 100 \\
\hline
\end{tabular}

\section{Tabel 8}

Spijt achteraf, naar belangrijkste reden voor de voortijdige uitval (\%)

\begin{tabular}{|l|r|r|r|r|r|r|}
\hline & $\begin{array}{r}\text { School- } \\
\text { gerelateerde } \\
\text { oorzaken }\end{array}$ & $\begin{array}{r}\text { (geestelijke) } \\
\text { gezondheids- } \\
\text { klachten }\end{array}$ & $\begin{array}{r}\text { Persoonlijke } \\
\text { problemen }\end{array}$ & Arbeidsmarkt \\
\hline 1 Nee & 56 & 37 & 28 & 59 \\
\hline 2 Ja, dat zou ik nu niet meer doen & 19 & 6 & 17 & 18 \\
\hline 3 Ja, maar ik kon destijds niet anders & 25 & 57 & 16 \\
\hline
\end{tabular}


die aangeven destijds niet anders te kunnen, heeft als reden van de uitval de arbeidsmarkt genoemd (23\%).

\section{Conclusies}

In deze fact sheet zijn cijfers gepresenteerd over jongeren jonger dan 23 jaar, die zijn uitgevallen in het voortgezet onderwijs en het middelbaar beroepsonderwijs en daarbij geen startkwalificatie voor de arbeidsmarkt hebben gehaald. De belangrijkste bevindingen zijn:

- Bijna de helft van de redenen die aangevoerd worden om te stoppen is schoolgerelateerd (47\%). Ook gezondheidsproblemen ( $18 \%$ ) en de lonkende arbeidsmarkt (I4\%) worden relatief vaak genoemd. Onderaan de lijst staat de categorie persoonlijke problemen $(9 \%)$. Het vaakst werden schoolgerelateerde problemen genoemd als redenen voor het stoppen met de opleiding op mbo niveau 3 en 4 (beide $5 \mathrm{I} \%$ ). Het minst werd deze reden aangevoerd door voortijdig schoolverlaters van het vmbo $(36 \%)$.

- Bij ongeveer 8 op de Io voortijdig uitvallers heeft er een gesprek plaatsgevonden over het voortijdig uitvallen van de opleiding ( $78 \%)$. Indien de respondent met iemand gesproken heeft, is dat in driekwart van de gevallen met de ouders $(77 \%)$, meer dan de helft van de respondenten praat met de school (56\%) en ongeveer drie op de tien respondenten praat met het gezin of vrienden over de aanstaande voortijdig uitval. In totaal hebben $65 \%$ van de voortijdig schoolverlaters hulp van iemand ervaren om het diploma te behalen of een andere opleiding te kiezen.

- Ongeveer vier op de tien voortijdig schoolverlaters is aan het werk (40\%), en ongeveer $29 \%$ is met een opleiding bezig en nog eens $\mathrm{II} \%$ is bezig met een werk/leertraject. Ongeveer $8 \%$ kan tot de werkloze beroepsbevolking worden gerekend, terwijl ongeveer $12 \%$ een andere bezigheid heeft.

- Van de voortijdig schoolverlaters die nog niet opnieuw een opleiding volgen, is $75 \%$ van plan om op een later tijdstip nog een opleiding te gaan volgen. Van de $75 \%$ heeft ongeveer $8 \%$-punt zich al ingeschreven voor een opleiding. Ongeveer $25 \%$ is van plan om in de toekomst geen opleiding meer te volgen. De meest genoemde afremmende factor om opnieuw aan een opleiding te beginnen, zijn de te hoge kosten die aan een opleiding verbonden zijn (28\%).

- Uit de antwoorden die de vsv'ers die nog niet opnieuw staan ingeschreven bij een opleiding hebben gegeven, blijkt dat vooral geld een rol speelt in het niet starten met een nieuwe opleiding. Van de respondenten geeft $37 \%$ aan dat financiële steun van de gemeente een stimulans zou kunnen zijn. Ongeveer $31 \%$ van de respondenten geeft aan dat ze een opleiding zouden kunnen starten als deze naast hun huidige baan zou kunnen worden gevolgd.

- Van alle vsv'ers heeft de helft (50\%) geen spijt van de keuze om voortijdig met de opleiding te stoppen. Dit percentage ligt voor vsv'ers afkomstig van het avo, vmbo, mbo niveau 3 en 4 allen rond de $55 \%$. Het laagst is dit percentage voor mbo niveau I (37\%). 


\section{Bijlagen}

Tabel B1

Achtergrondkernmerken respondenten

\begin{tabular}{|c|c|c|c|c|c|c|c|}
\hline & AVO & VMBO & MBO 1 & $\mathrm{MBO} 2$ & $\mathrm{MBO} 3$ & $\mathrm{MBO} 4$ & Totaal \\
\hline Totaal & 12 & 8 & 7 & 33 & 13 & 28 & 100 \\
\hline \multicolumn{8}{|l|}{ Sector } \\
\hline Landbouw & & 2 & 1 & 4 & 6 & 3 & 3 \\
\hline Techniek & & 8 & 14 & 38 & 17 & 22 & 23 \\
\hline Economie & & 8 & 67 & 39 & 45 & 41 & 35 \\
\hline Gezondheidszorg & & 5 & 7 & 18 & 18 & 18 & 14 \\
\hline Gedrag \& maatschappij & & & & & 14 & 15 & 6 \\
\hline Niet nader te specificeren sector & 100 & 78 & 12 & & & & 19 \\
\hline
\end{tabular}

\section{Leerweg}

Theoretisch

62

Gemengd

Kaderberoepsgericht

6

Basisberoepsgericht

6

Leeftijd (gemiddelde)

19,6

18,3

20

20,37

20,32

20,36

20,1

Man

$62 \quad 65$

Vrouw

38

$65 \quad 70$

66

58

56

62

Etniciteit

Westerse allochtoon

9

35

30

34

42

44

Niet-westerse allochtoon

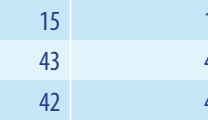

12

\begin{tabular}{|r|r|r|r|}
\hline 6 & 10 & 9 & 9 \\
\hline 31 & 21 & 29 & 30 \\
\hline 63 & 69 & 63 & 62 \\
\hline
\end{tabular}

\section{Gezinssituatie}

Tweeoudergezin

$63 \quad 60$

Eenoudergezin

Zelfstandig

Anders

44

44

31

28

56
35
8

\section{6}

64

55

58

7

8

16

\section{Gesproken taal thuis}

(Bijna) altijd Nederlands

Nederlands en een andere taal

(Bijna) altijd een andere taal

Niet van toepassing

\begin{tabular}{|l|l|}
\hline 75 & 50 \\
\hline 12 & 24 \\
\hline 4 & 12 \\
\hline 9 & 14 \\
\hline
\end{tabular}

Opleidingsniveau ouders

Basisonderwijs

Lager beroepsonderwijs (lbo/vbo/vmbo/mavo)

Voortgezet onderwijs (havo/vwo)

Middelbaar beroepsonderwijs

Hoger onderwijs

\begin{tabular}{|r|r|r|}
\hline 2 & 9 & 14 \\
\hline 8 & 14 & 16 \\
\hline 5 & 9 & \\
\hline 16 & 15 & 30 \\
\hline 69 & 53 & 3 \\
\hline
\end{tabular}

\begin{tabular}{|r|r|r|r|r|}
\hline 56 & 62 & 72 & 69 & 65 \\
\hline 22 & 20 & 14 & 17 & 18 \\
\hline 8 & 7 & 5 & 6 & 6 \\
\hline 14 & 11 & 10 & 9 & 11 \\
\hline
\end{tabular}


Tabel B2

Belangrijkste reden voortijdige uitval

\begin{tabular}{|c|c|c|c|c|c|c|c|c|}
\hline & & AVO & VMBO & MB0 1 & $\mathrm{MBO} 2$ & $\mathrm{MBO} 3$ & MBO 4 & Totaal \\
\hline \multirow[t]{10}{*}{ Schoolgerelateerde oorzaken } & $\begin{array}{l}\text { De opleiding was te moeilijk en/of gezakt voor het } \\
\text { eindexamen }\end{array}$ & 22 & 7 & 3 & 6 & 5 & 4 & 7 \\
\hline & Problemen op de leerwerkplek/stage (bijv. ontslag) & 1 & 1 & 4 & 6 & 5 & 3 & 4 \\
\hline & Problemen met de leraren/schoolleiding & 4 & 6 & 5 & 5 & 4 & 4 & 5 \\
\hline & Problemen met andere leerlingen & 1 & 2 & 1 & 2 & 0 & 1 & 1 \\
\hline & Ik wilde van opleiding wisselen & 5 & 9 & 3 & 5 & 6 & 6 & 5 \\
\hline & Ik voelde me niet veilig op de school & 1 & 3 & & 1 & 0 & 0 & 1 \\
\hline & De opleiding was inhoudelijk (toch) niet wat ik wilde & 5 & 4 & 8 & 11 & 18 & 19 & 13 \\
\hline & Ik vond het niveau van de opleiding te laag & 2 & 6 & 10 & 4 & 3 & 4 & 4 \\
\hline & De opleiding was slecht georganiseerd & 5 & 4 & 3 & 9 & 8 & 9 & 8 \\
\hline & Geen stageplek kunnen vinden & 0 & & 8 & 4 & 3 & 3 & 3 \\
\hline Subtotaal & & 43 & 36 & 41 & 49 & 51 & 51 & 47 \\
\hline \multirow[t]{3}{*}{ (Geestelijke) gezondheidsklachten } & Ziekte & 9 & 7 & 7 & 6 & 9 & 9 & 8 \\
\hline & Verslavingsproblemen & 3 & 1 & 2 & 1 & 1 & 1 & 2 \\
\hline & Psychische problemen & 14 & 9 & 11 & 7 & 11 & 13 & 10 \\
\hline Subtotaal & & 24 & 16 & 20 & 11 & 19 & 23 & 18 \\
\hline \multirow[t]{4}{*}{ Persoonlijke problemen } & $\begin{array}{l}\text { Relatieproblemen/gezinsproblemen (bijv. scheiding van } \\
\text { ouders }\end{array}$ & 7 & 8 & 7 & 6 & 8 & 6 & 7 \\
\hline & Zwangerschap & & 2 & & 1 & 0 & 1 & 1 \\
\hline & $\begin{array}{l}\text { School in combinatie met zorg voor kinderen en/of familie } \\
\text { was te zwaar }\end{array}$ & 1 & & 1 & 2 & 1 & 1 & 1 \\
\hline & In aanraking gekomen met politie/justitie & & 4 & & 1 & & 1 & 1 \\
\hline Subtotaal & & 8 & 13 & 9 & 10 & 9 & 8 & 9 \\
\hline \multirow[t]{2}{*}{ Arbeidsmarkt } & Ik wilde liever gaan werken & 6 & 13 & 19 & 14 & 7 & 7 & 10 \\
\hline & Ik had een inkomen nodig en ben daarom gaan werken & 1 & 4 & 2 & 4 & 7 & 4 & 4 \\
\hline Subtotaal & & 7 & 17 & 22 & 18 & 13 & 10 & 14 \\
\hline \multirow[t]{2}{*}{ Anders } & Ik ging verhuizen & 1 & 8 & & 2 & 1 & 1 & 1 \\
\hline & Anders & 12 & 5 & 5 & 3 & 3 & 4 & 5 \\
\hline Subtotaal & & 19 & 19 & 9 & 12 & 9 & 9 & 12 \\
\hline
\end{tabular}




\section{Schoolverlatersinformatiesysteem}

\section{Een openbaar toegankelijke bron van data}

\section{Algemeen}

De subsidiemiddelen beschikbaar gesteld door het Ministerie van Onderwijs, Cultuur en Wetenschap, het Ministerie van Economische Zaken en het Ministerie van Sociale Zaken en Werkgelegenheid maken de basisvoorziening mogelijk. De databestanden zijn daarbij vrij toegankelijk en maken daarmee een breed pallet van strategisch onderzoek mogelijk, van proefschriften, wetenschappelijke beleidsrelevante artikelen tot landelijke beleidsrapportages. De jaarlijkse databestanden afkomstig van het SchoolverlatersInformatieSysteem zijn beschikbaar via www.dans.knaw.nl. Voor ondersteuning bij het gebruik van de databestanden zijn de onderzoekers van het ROA bereikbaar via secretary-roa-sbe@maastrichtuniversity.nl

Cijfers afkomstig van het
SchoolverlatersInformatieSysteem zijn recent onder andere gebruikt voor:

- Studiekeuze I23 website;

- Studie in cijfers;

- Keuzegids MBO, Keuzegids HBO;

- Onderwijs in Cijfers van het Ministerie van OCW;

- Commissie Macrodoelmatigheid: Arbeidsmarktperspectief mbo niveau 2;

- SCP: Eerste treden op de arbeidsmarkt;

- Onderwijsinspectie: De staat van het onderwijs onderwijsverslag;

- Onderwijsinspectie: Beginnende leraren kijken terug, deel I: de pabo;

- Onderwijsinspectie: Beginnende leraren kijken terug, deel 2: de Tweedegraads Lerarenopleidingen;

- SEO/ECBO/ROA: Klaar voor de groei: Monitor uitrol Associate degree;

- $\mathrm{MBO}$ raad: Feiten en cijfers;

- ECBO: Het Nederlandse onderwijs geketend: Doorstroom in en tussen vo en mbo;

- ECBO: De kleur van het middelbaar beroepsonderwijs: Een overzichtsstudie naar allochtonen in het mbo;

- Innovatieplatform: Kennis en Innovatie Agenda $201 \mathrm{-}-2020$

\section{Website Kerncijfers Schoolverlatersonderzoeken: \\ https://roastatistics.maastrichtuniversity.nI/SISOnline/Home. aspx}

Op de website Kerncijfers Schoolverlatersonderzoeken (https://roastatistics.maastrichtuniversity.nl/SISOnline/ Home.aspx) zijn meerjarige landelijke statistieken te vinden over gediplomeerde schoolverlaters van het initiële onderwijs in Nederland. De cijfers zijn gebaseerd op de schoolverlatersonderzoeken van het ROA (in samenwerking met CBS en DESAN Resarch Solutions) en hebben betrekking op de gediplomeerden van het avo, vmbo, mbo en het hbo. De kerncijfers die gepresenteerd worden geven een inzicht in de gevolgde studie, het vervolgonderwijs en de intrede van de schoolverlaters op de arbeidsmarkt.

De website is te raadplegen vanuit twee invalshoeken: naar onderwijsindeling en naar kernindicator. De invalshoek naar onderwijs laat alle kerncijfers voor een bepaalde onderwijsindeling zien. Hierbij kan gekozen worden voor onderwijsniveaus, onderwijssectoren en individuele opleidingen. Daarnaast is er de mogelijkheid om een keuze te maken voor voltijd, deeltijd of duale opleidingsvarianten. De invalshoek naar indicator laat voor alle onderwijsniveaus, - sectoren dan wel opleidingen de informatie over één gekozen indicator zien. Zowel in het menu als in de overzichtstabellen zijn de kernindicatoren naar een vijftal categorieën ingedeeld:

- algemene achtergrondkenmerken;

- gevolgde opleiding;

- oordeel over de gevolgde opleiding;

- kenmerken vervolgonderwijs;

- arbeidsmarktindicatoren en baankenmerken.

De cijfers worden telkens, zover mogelijk, weergegeven voor de laatste vijf meetjaren en worden jaarlijks geüpdatet rond de tijd dat het landelijk rapport 'Schoolverlaters tussen Onderwijs en Arbeidsmarkt' uitkomt.

De website biedt daarnaast uitgebreide informatie over de methodologische aanpak van het Schoolverlatersinformatiesysteem (SIS) alsmede een verantwoording van de respons. 


\section{Colofon}

(C) Researchcentrum voor Onderwijs en Arbeidsmarkt (ROA). Niets uit deze uitgave mag op enige manier worden verveelvoudigd zonder voorafgaande schriftelijke toestemming van de directeur van het ROA.

Researchcentrum voor Onderwijs en Arbeidsmarkt Maastricht University

School of Business and Economics

secretary-roa-sbe@maastrichtuniversity.nl

www.roa.nl

Vormgeving

ROA secretariaat, Maastricht 
Researchcentrum voor Onderwijs en Arbeidsmarkt

Postbus 616

6200 MD Maastricht

$\mathrm{T}+31433883647$

F +31 433884914

secretary-roa-sbe@maastrichtuniversity.nl

www.roa.nl

Maastricht University

School of Business and Economics 